\title{
Human Capital Development as a Requisite for Organizational Performance Within Private Universities in Kenya
}

\author{
Bonn Odera Jonyo, DBA \\ Caren Ouma Ph.D. Associate Professor \\ Zachary Mosoti Ph.D. Assistant Professor \\ United States International University, Africa
}

Doi: 10.19044/ejes.v5no2a5

URL:http://dx.doi.org/10.19044/ejes.v5no2a5

\begin{abstract}
Sub-Saharan Africa trails other regions in the realm of key human development indicators, produces less than 1 percent of the global research output despite having 12.5 percent of the global population. If the region is to improve on its human capital development indicators, it must embrace action research in addressing the many developmental challenges facing it. The purpose of the study was to examine human capital development as a requisite for organizational performance in private universities in Kenya. The research question was how does human capital affect organization performance in private universities in Kenya? This was a correlational study which adopted a positivist research philosophy. The study population comprised of all the 17 private universities in Kenya accredited by Commission of University Education. A census technique was used in the study with frequency distributions, percentages and means were used in descriptive statistical analysis while, correlations and regression analysis were used for inferential statistics. The study found that human capital development explained a significant proportion of variance in organizational performance, $\mathrm{R}^{2}=.515$. Human capital development significantly predicted organizational performance, $\beta=.718, t(122)=11.336, p=.000$. The study concluded that there was a significant relationship between human capital development and organizational performance the dependent variable.
\end{abstract}

Keywords: Strategic leadership, human capital, high performance, work force, indicators. 


\section{Introduction}

The 21 st century is witnessing the largest period of considerable transformation in education ever experienced by any civilization. The new information age that will test future existence of schooling and the thinking orientation. Universities need clear strategic plans that focus on practical applications and include comprehensive roadmaps for moving research from the lab to the market place to be innovative. They also need to define how best to recruit, retain, and prepare future manpower. The changes experienced in higher education is a global phenomenon because of expansion in the sector due to population increase. It is comprised of diversification of services and products, provision of more heterogeneous student government, new funding arrangements, increasing focus on accountability and performance, global networking, mobility, collaboration and strategic leadership issues (Lemaitre, 2009).

Human capital can be defined as the sum of a person's knowledge and skills that the organization can us to further its objectives and goals (Ireland \& Hitt, 2015). The knowledge, skills, competencies and other attributes embodied in individuals or groups of individuals acquired during their life and used to produce goods, services or ideas in market environment are very critical for any organization. Therefore, the aggregate human capital of an economy, is determined by the quality and level of national educational standards. In most universities and colleges, emphasis is put mainly on management but not on leadership which is understood as a process that involves setting directions, motivating others and coping with change. Morrill (2010) further emphasizes that, it requires integrative and systematic thinking, quantitative reasoning, collaborative decision making, effective communication, sensitivity to narratives and values, and a capacity to work in structured group processes.

Expansion of higher education in sub-Saharan Africa was possible in the past only through state universities, which had a near monopoly in providing higher education in African countries during the post-independence period. The financial crisis of the state compromised its ability to fund an expansion foundation of higher education in Africa. The market friendly reforms and deregulation policies initiated under the structural programmes, the privatization of public sector units, and the encouragement of the private sector in the context of the globalization process created a motivating environment for the emergence of the private higher education sector in Africa (Varghese, 2006). The opening up of a market economy (globalization) has partly contributed to an increasing number of private universities in Africa among others, absorb the spill-over from the pool of fully qualified but unsuccessful applicants to state universities and to offer a limited range of programmes which are market driven (Sawyer, 2004). These challenges 
motivated the examination of how human capital development affects organizational performance in private schools in Kenya.

\section{Research Problem}

In the past one decade, statistics show a big number of youthful population from developing countries pursue tertiary education outside their home countries (UNESCO, 2014). This implies that there is a high demand for university education among the youth in developing countries. In Kenya, the high demand for university education piles pressure on public universities leading to the establishment of private universities to accommodate students who miss opportunities in public universities. Based on the global webometric ranking of universities (2016), private universities in Kenya were not competitive and this low ranking begs the question whether it was due to poor leadership to hire quality high performing human resource because the strategic leadership theory which underpins this study holds that organizations are reflections of their top executives. The question is whether this failure is due to lack of human capital development in strategic leadership? This study therefore sought to examine human capital development as a requisite for organizational performance within private universities in Kenya.

\section{LITERATURE REVIEW}

The theoretical orientation of the study was based on the strategic leadership theory which asserts that companies are reflections of their top managers and, the chief executive officers, and that the specific knowledge, experience, values and preferences of top managers as reflected in their assessments of decision environments (Ireland et al., 2013).

\section{Conceptual Framework}

A conceptual framework is the researcher's understanding of how the variables in the study associate with each other. It is the researcher's "map" in pursuing the investigation. The conceptual framework for this study was derived from the strategic leadership theory as developed by Ireland and Hitt (2013). 


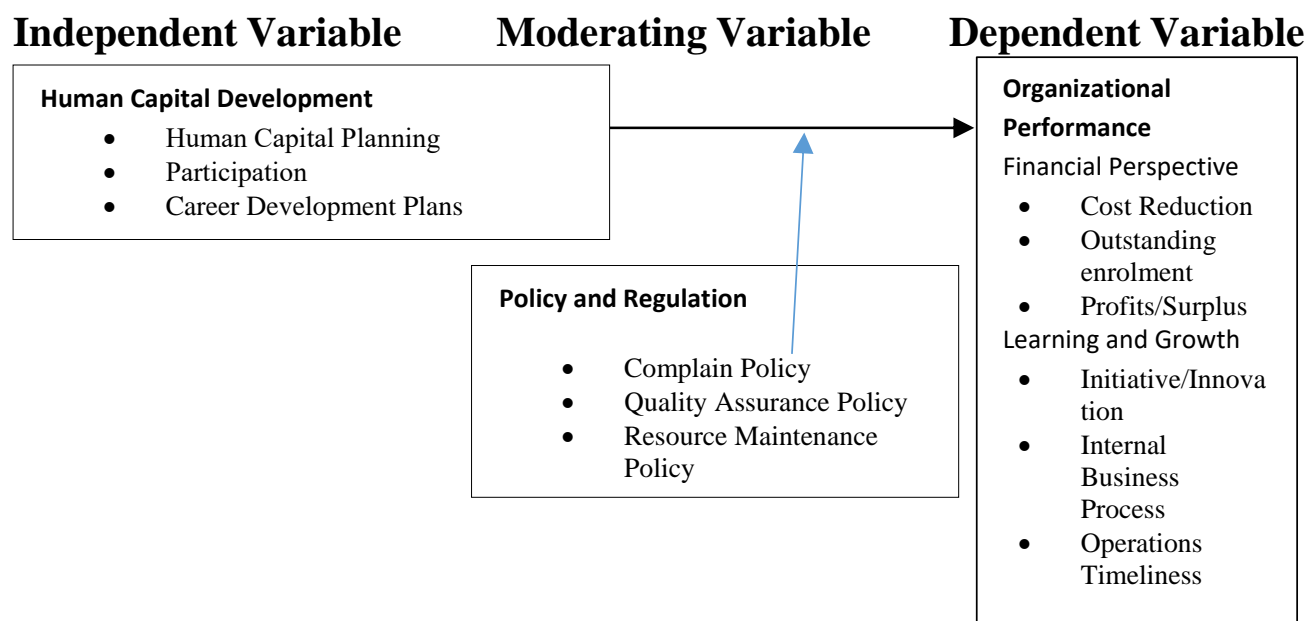

Source: Researcher

The following null hypothesis derived from the research question guided the study:

$H_{01}$ Development of human capital does not affect organizational performance in private universities in Kenya

According to Ireland and Hitt, (2013), human capital competencies are exhibited by the workforce in terms of knowledge and skills in an organization. Strategic leaders view organizational workforce as a pivotal resource that forms the building block for the core competencies through which competitive advantages are exploited successfully.

\section{Developing Human Capital}

Organizations compete for market access and dominance in the global arena of their products, services and resources and this can only be realized with a well capacitated human resource with skills like superior customer care and retention, marketing forecast, sales and technological savviness. This will give an organization a competitive edge over the competition. A motivated human resource is the beginning of an organizational success because employees have benefits such as; stock options, bonuses, good medical schemes and retirement packages (Truss, Mankin, \& Kelliher, 2012). Consequently, this study will examine the contribution of human capital as the most valuable resource in universities' growth and success.

Knowledge attracts superior intellectual skills to individuals, thus considering their productivity and efficiency potential to develop activities according to the human capital theory (Lemieux, 2006). Past studies have established that the variables of human capital and social capital are strongly and positively correlated with organizational performance (Dimov \& Shepherd, 2005). Essentially organizations flourish when its human resource 
empowered and motivated. The positive outcomes will just exhibit themselves in staff responsiveness to institutional activities.

An assessment of how organizational performance is designed, is critical in comprehending how to gauge the success of organizations, recognizing the fundamental role of the cognitive ability of the top executive (Felício, Couto \& Caiado, 2014). The other factors of human capital and social capital are critical in providing building blocks for the success but do not directly control organizational performance. Key components like job experience, management experience and prior entrepreneurial experience are associated to organizational action (Dimov and Shepherd, 2005).

An organization's management team must take cognizance of the fact that modern institutions change so fast that everything is dependent on its human capital adaptability (Kamukama, Ahiauzu \& Ntayi, 2010). This implies that even university boards' performance of their roles is dependent on the human capital residing in people in the organizations. It confirms how central the role of human capital is to the success of the organization.

\section{Human Capital}

\begin{tabular}{|l|}
\hline Knowledge \\
\hline Experience \\
\hline Professional proficiency \\
\hline Cognitive ability \\
\hline
\end{tabular}

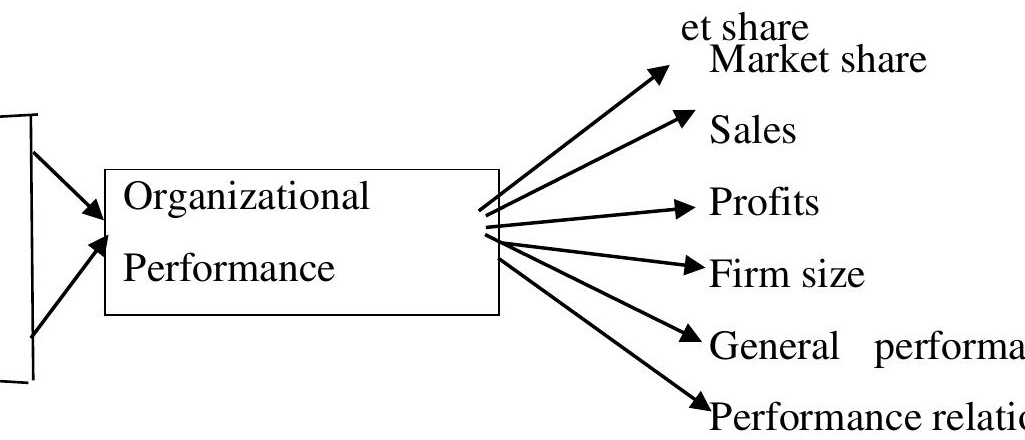

\section{Hypothesized model of causal structure linking human capital and performance}

Source: Ireland et al., (2016).

An organizations' human capital is the most important resource of a sustained competitive advantage (Hitt et al., 2016) and therefore investments in the human capital of the workforce may increase employee productivity and financial results. The knowledge, skills and abilities as possessed by organizational employees (Felício, Couto and Caiado (2014), is a critical valuable resource that drives profit generation. Lim, Chan and Dallimore, (2009) submits that organizations secure, develop, reward and retain their key talents and human capital to nurture knowledge-based competency and to improve productivity. As a consequent, Ployhart, van-Iddekinge and Mackenzie (2011) argues that the dimension and reporting of human capital 
stock, flow and quality is essential to the effective management of the critical resource (Beattie \& Smith, 2010). Managers who have appropriate aptitude of organizational human resource often makes informed decisions to leverage the knowledge, skills and abilities of employees to get a competitive advantage. Universities need capable and competent leaders to manage human capital as many studies have demonstrated to improve performance.

Huselid and Becker (2011) submits that a sustainable competitive advantage is achievable when, organizations adopt the best human resource practices to manage their valuable and talented employees. High-performance human resource practice is a management approach that integrates different set of HR management practices to improve business performance and Gurbuz, (2009) adds that, it is also known as best HR management practices and progressive HR management.

Organizations that implement best practices often achieves better performance in service delivery (Boxall \& Purcell, 2003). Khasawneh and Alzawahreh, (2012) although there is no consensus about high-performance, HR practices have been used by majority of researchers as high-performance HR practices; extensive training (Wei, Han \& Hsu, 2010), performance management (Huselid \& Becker, 2011; Posthuma, Campion, Masimova \& Campion, 2013), performance appraisal (Posthuma et al., 2013), performancebased compensation (Gupta \& Singh, 2010; Gurbuz, 2009; Huselid \& Becker, 2011; Wei et al., 2010), empowerment (Gupta \& Singh, 2010; Gurbuz, 2009) and competency development (Gupta \& Singh, 2010). The high performance of $\mathrm{HR}$ in organizations is only sustainable through a progressive transformational management outfit which is strategic leadership to create change in the fortunes based on the objectives and goals.

According to Standa, (2007) visionary and creative leadership is critical to the transformation of higher education. Further, it should be noted that reforming leadership, governance and management systems of each institution should take precedence and recommended that administrative and management structures of the universities should be evaluated and restructured to create efficient, effective, responsive and functional structures to avoid wastage of resources, duplicated responsibilities and overlapping mandates where members of different levels are members at next level and to institute checks and balances. Good governance creates partnerships and participation to represent proactivity. Choi and Lee (2013) adds that the authority to make decisions should be delegated to operational units (schools, institutes and departments). The hiring of deans, directors of institutes, heads of departments, administrators and managers for the operational units should be done competitively via meritocracy at all levels and remuneration be pegged to competence and performance. This takes cognizance of meritocracy to mitigate hiring of mediocre workforce. 
Breakwell and Tytherleigh, (2010) found evidence for the importance of vice chancellors' characteristics for institutional performance to be limited but support the notion that whilst the performance of a university may be molded by the characteristics of its leader, most of the variability in university performance is explained by non-leadership factors. Many scholars attest to this fact because VC's should be all rounded managers of the university (Wei \& Lau, 2010). According to Absar, Nimalathasan and Jilani (2010), business performance is dependent on the skill, knowledge and experience of the employees. Efficient and unique human pool helps the organization to achieve this goal through resource utilization effectiveness, innovation, employees and customers' satisfaction and better quality of products or services.

According to Nel and Beudeker (2009), human capital is the totality of competencies within the entire workforce in terms of knowledge and skills. Strategic leaders view organizational workforce as a crucial resource and forms the building block on the core competencies through which competitive advantages are exploited successfully. Significant investments will be obligatory for the organization to stem full competitive advantages from its human capital in the global economy. Economists contend that these investments are critical to strong long-term growth in modern economies that depend on knowledge, skills and information technology. Consistent research and systematic work on the productivity of knowledge and workers, enhances the organizations' ability to perform successfully. Employees appreciate the opportunity to learn continuously and feel greater involvement with their community when encouraged to expand their knowledge base. Developing employees result in a motivated and well educated and skilled workforce which contributes to organization success.

\section{Organizational Performance}

Armstrong (2017) defines performance as the record of outcomes produced on a specified job function or activity during a specified period. Consequently, performance is measured in terms of output and outcome, profit, internal processes and procedures, organizational structures, employee attitudes, and organizational responsiveness to the environment among others. The capabilities and skills leaders should employ must contain mentoring and coaching, leading and motivating, problem solving and decision making, communicating and listening, and influencing and negotiating which form succession plans (Tomal \& Jones, 2015). A relationship between leadership competencies and cognitive competencies exists.

\section{Policy and Regulation}

The main regulator of university education in Kenya is Commission for University Education. The policy on education and training then envisages 
a curriculum that successively develops the knowledge, skills, competencies, as well as continuous learning dispositions of its candidates to meet the human capital needs of the country. This ensures that learners are getting quality education and training. The Commission considers issues such as the effectiveness of government education policy implementation, strategic planning, resource mobilization and the management of resources by Ministries and institutions concerned with education and their management bodies.

\section{METHODOLOGY}

The study adopted positivism as the research philosophy which is premised on measurable observations that lead themselves to statistical analysis (Cooper \& Schindler, 2014). The correlational method was used for this study because of a wide range of variables and their interrelatedness (Creswell, 2014). The design was deemed suitable because this study focused on examining the effect of human capital development as a factor on organizational performance. The target population for this study included all the 17-chartered private which by Commission of University Education (CUE, 2016) with a total of 136.

The study adopted a census study in line with Israel (2009) and Rao (2015) recommendations that sample sizes of less than 200 are studied to cater for any non-response that may be encountered in the study. The estimated sample size of 136 respondents was distributed proportionate to the size of the population. The main tool for data collection was a questionnaire, preferred because it possesses a high rate of response and that the respondents can respond to the questions simultaneously hence saving time. Reliability was tested using the Cronbach's alpha with a coefficient of at least 0.7 . The validity of the study was ascertained by subject experts. Descriptive statistics was used to present the data into charts and tables with frequency distribution and percentages as well as means and standard deviations. Inferential statistics was used test the hypothesised relationships between the independent and dependent variable, with correlation and regression analyses.

\section{Diagnostic tests}

Normality test was done in the study to determine if the data set is wellmodelled by a normal distribution. Multicollinearity was done in the study using the variance inflation factors (VIF) for each variable using traditional criteria employed in the study. Linearity - The study conducted linearity test to determine whether the relationship between each of the independent variable and dependent variable was linear or not. The study findings had the homoscedasticity test evaluated for pairs of variables using the Levene statistic for the test of homogeneity of variances 


\section{FINDINGS AND RESULTS}

The study examined human capital development as a requisite for organizational performance in private universities in Kenya. Data was analyzed at two levels where the first level entailed determining human capital development. The second part involved analyzing results on the effect of human capital development on organizational performance.

Table 1 Means and Standard Deviations for Human Capital Development

\begin{tabular}{|l|l|l|l|}
\hline & $\mathrm{N}$ & $\begin{array}{l}\text { Mean } \\
\text { (M) }\end{array}$ & $\begin{array}{l}\text { Std. } \\
\text { Deviation } \\
\text { (SD) }\end{array}$ \\
\hline $\begin{array}{l}\text { The university integrates human capital planning as a } \\
\text { factor to organizational performance }\end{array}$ & 124 & 3.8145 & .84936 \\
\hline $\begin{array}{l}\text { There is a participation of employees in the formulation of } \\
\text { human resource plan }\end{array}$ & 124 & 3.2500 & 1.06401 \\
\hline $\begin{array}{l}\text { In the university, human resource planning is a strategic } \\
\text { issue. }\end{array}$ & 123 & 3.8862 & .99345 \\
\hline $\begin{array}{l}\text { The university operates training and development plan as } \\
\text { a result of human resource planning }\end{array}$ & 123 & 3.6179 & 1.06756 \\
\hline $\begin{array}{l}\text { There is annual budget set for the operationalization of the } \\
\text { human resource planning in the university }\end{array}$ & 122 & 3.8033 & .89664 \\
\hline $\begin{array}{l}\text { Human resource planning is well organized in the } \\
\text { university }\end{array}$ & 122 & 3.4836 & 1.08509 \\
\hline $\begin{array}{l}\text { In the university, top level management supports the } \\
\text { operationalization of the human resource planning }\end{array}$ & 122 & 3.7295 & .85316 \\
\hline The university has optimum number of employees & 121 & 3.1405 & 1.18537 \\
\hline The university has only engaged qualified professionals & 120 & 3.4000 & 1.06432 \\
\hline $\begin{array}{l}\text { The university has employees with the desired levels of } \\
\text { education }\end{array}$ & 122 & 3.8689 & .94432 \\
\hline The university has clear career development plans & 121 & 3.5620 & 1.15392 \\
\hline
\end{tabular}

The study also sought to analyze the views of respondents on human capital development using a table of means and standard deviations. A Likert scale data was collected rating the views in a scale. The mean results are therefore given on a scale interval where a mean value of up to 1 is an indication of strongly disagree; 1 . disagree; 2. Neutral: 3. Agree: 4 and strongly agree:5. Findings on human capital development are shown in Table 1.

\section{Correlation between Human Capital Development and Organizational Performance}

The study correlated human capital development and organizational performance and found that all the items of human capital development were positively and significantly related with organizational performance as shown on Table 2. 
Table 2 Correlation between Human Capital Development and Organizational Performance for All Items

\begin{tabular}{|c|c|c|}
\hline & & Performance \\
\hline \multirow{3}{*}{$\begin{array}{l}\text { The university integrates human capital planning as } \\
\text { a factor to organizational performance }\end{array}$} & Pearson Correlation & $.484^{* * *}$ \\
\hline & Sig. (2-tailed) & .000 \\
\hline & $\mathrm{N}$ & 123 \\
\hline \multirow{3}{*}{$\begin{array}{l}\text { There is a participation of employees in the } \\
\text { formulation of human resource plan }\end{array}$} & Pearson Correlation & $.520^{* *}$ \\
\hline & Sig. (2-tailed) & .000 \\
\hline & $\mathrm{N}$ & 123 \\
\hline \multirow{3}{*}{$\begin{array}{l}\text { In the university, human resource planning is a } \\
\text { strategic issue. }\end{array}$} & Pearson Correlation & $.438^{* *}$ \\
\hline & Sig. (2-tailed) & .000 \\
\hline & $\mathrm{N}$ & 123 \\
\hline \multirow{3}{*}{$\begin{array}{l}\text { The university operates training and development } \\
\text { plan as a result of human resource planning }\end{array}$} & Pearson Correlation & $.584^{* * *}$ \\
\hline & Sig. (2-tailed) & .000 \\
\hline & $\mathrm{N}$ & 123 \\
\hline \multirow{3}{*}{$\begin{array}{l}\text { There is annual budget set for the operationalization } \\
\text { of the human resource planning in the university }\end{array}$} & Pearson Correlation & $.490^{* * *}$ \\
\hline & Sig. (2-tailed) & .000 \\
\hline & $\mathrm{N}$ & 122 \\
\hline \multirow{3}{*}{$\begin{array}{l}\text { Human resource planning is well organized in the } \\
\text { university }\end{array}$} & Pearson Correlation & $.514^{* *}$ \\
\hline & Sig. (2-tailed) & .000 \\
\hline & $\mathrm{N}$ & 122 \\
\hline \multirow{3}{*}{$\begin{array}{l}\text { In the university, top level management supports the } \\
\text { operationalization of the human resource planning }\end{array}$} & Pearson Correlation & $.612^{* * *}$ \\
\hline & Sig. (2-tailed) & .000 \\
\hline & $\mathrm{N}$ & 122 \\
\hline \multirow{3}{*}{ The university has optimum number of employees } & Pearson Correlation & $.383^{* *}$ \\
\hline & Sig. (2-tailed) & .000 \\
\hline & $\mathrm{N}$ & 121 \\
\hline \multirow{3}{*}{$\begin{array}{l}\text { The university has only engaged qualified } \\
\text { professionals }\end{array}$} & Pearson Correlation & $.395^{* *}$ \\
\hline & Sig. (2-tailed) & .000 \\
\hline & $\mathrm{N}$ & 120 \\
\hline \multirow{3}{*}{$\begin{array}{l}\text { The university has employees with the desired levels } \\
\text { of education }\end{array}$} & Pearson Correlation & $.442^{* *}$ \\
\hline & Sig. (2-tailed) & .000 \\
\hline & $\mathrm{N}$ & 122 \\
\hline \multirow{3}{*}{ The university has clear career development plans } & Pearson Correlation & $.489^{* *}$ \\
\hline & Sig. (2-tailed) & .000 \\
\hline & $\mathrm{N}$ & 121 \\
\hline \multirow{3}{*}{$\begin{array}{l}\text { The university has put in place training on } \\
\text { management practices }\end{array}$} & Pearson Correlation & $.591^{* *}$ \\
\hline & Sig. (2-tailed) & .000 \\
\hline & $\mathrm{N}$ & 122 \\
\hline \multirow{3}{*}{ Organizational Performance } & Pearson Correlation & 1 \\
\hline & Sig. (2-tailed) & \\
\hline & $\mathrm{N}$ & 123 \\
\hline
\end{tabular}

**. Correlation is significant at the 0.01 level (2-tailed). 
The study sought to determine the relationship between human capital development index and organizational performance using correlation analysis and found that the two variables were strongly correlated $r(123)=.718, p=$ .000 . The results are as shown in Table 3 .

Table 3 Correlation Analysis on Human Capital Development Index

\begin{tabular}{|l|l|l|}
\hline \multicolumn{2}{|l|}{} & $\begin{array}{l}\text { Organizational } \\
\text { Performance }\end{array}$ \\
\hline \multirow{3}{*}{ Human Capital Development } & Pearson Correlation & $.718^{* *}$ \\
\cline { 2 - 3 } & Sig. (2-tailed) & .000 \\
\cline { 2 - 3 } & $\mathrm{N}$ & 123 \\
\hline
\end{tabular}

**. Correlation is significant at the 0.01 level (2-tailed).

\section{One Way ANOVA on Human Capital Development}

A one-way ANOVA was carried out to establish if there was significant difference between the mean of human capital development with number of years in leadership position at the private universities as well as the current leadership position. The tests established that the mean for human capital development were the same for the number of years in leadership position $F(2,113)=0.045, p=0.956$. The study also found out that the mean for human capital development were the same for the current leadership position, $F(3,121)=1.305, p=0.276$. Table 4 presents these results.

Table 4 One Way ANOVA for Human Capital Development

\begin{tabular}{|c|c|c|c|c|c|}
\hline \multicolumn{6}{|c|}{ Human Capital Development and Years in Leadership Position } \\
\hline & Sum of Squares & $\mathrm{df}$ & Mean Square & $\mathrm{F}$ & Sig. \\
\hline Between Groups & .041 & 2 & .021 & .045 & .956 \\
\hline Within Groups & 51.173 & 111 & .461 & & \\
\hline Total & 51.215 & 113 & & & \\
\hline \multicolumn{6}{|c|}{ Human Capital Development and Current Leadership Position } \\
\hline & Sum of Squares & df & Mean Square & $\mathrm{F}$ & Sig. \\
\hline Between Groups & 1.930 & 3 & .643 & 1.305 & .276 \\
\hline Within Groups & 58.174 & 118 & .493 & & \\
\hline Total & 60.104 & 121 & & & \\
\hline
\end{tabular}

\section{Assumptions for Regression on Human Capital Development}

The study conducted the assumptions of regression to determine whether regression analysis was suitable in the study or not. The diagnostic tests conducted in the study included normality, linearity, homoscedasticity and multicollinearity tests.

\section{Normality Test for Human Capital Development}

The study checked the normality of the data set by looking at descriptive values of skewness and kurtosis. The skewness values obtained in the study indicated that the scores are skewed as all are negatively skewed and not that much closer to zero. The kurtosis values also fall within the range of -1 to +1 , and therefore do not display excessive kurtosis as well. These results 
suggest that the normality assumption is not violated in the study. Table 5 gives the results from the study.

Table 5 Normality Test for Human Capital Development

\begin{tabular}{|l|l|l|l|l|l|}
\hline & $\mathrm{N}$ & Skewness & \multicolumn{2}{l}{ Kurtosis } \\
\cline { 2 - 6 } & Statistic & Statistic & $\begin{array}{l}\text { Std. } \\
\text { Error }\end{array}$ & Statistic & $\begin{array}{l}\text { Std. } \\
\text { Error }\end{array}$ \\
\hline $\begin{array}{l}\text { The university integrates human capital } \\
\text { planning as a factor to organizational } \\
\text { performance }\end{array}$ & 124 & -.766 & .217 & .999 & .431 \\
\hline $\begin{array}{l}\text { There is a participation of employees in the } \\
\text { formulation of human resource plan }\end{array}$ & 124 & -.311 & .217 & -.626 & .431 \\
\hline $\begin{array}{l}\text { In the university, human resource planning is } \\
\text { a strategic issue. }\end{array}$ & 123 & -.533 & .218 & -.529 & .433 \\
\hline $\begin{array}{l}\text { The university operates training and } \\
\text { development plan as a result of human } \\
\text { resource planning }\end{array}$ & 123 & -.745 & .218 & .175 & .433 \\
\hline $\begin{array}{l}\text { There is annual budget set for the } \\
\text { operationalization of the human resource } \\
\text { planning in the university }\end{array}$ & 122 & -.649 & .219 & .464 & .435 \\
\hline $\begin{array}{l}\text { Human resource planning is well organized in } \\
\text { the university }\end{array}$ & 122 & -.431 & .219 & -.400 & .435 \\
\hline $\begin{array}{l}\text { In the university, top level management } \\
\text { supports the operationalization of the human } \\
\text { resource planning }\end{array}$ & 122 & -.665 & .219 & .343 & .435 \\
\hline $\begin{array}{l}\text { The university has optimum number of } \\
\text { employees }\end{array}$ & 121 & -.124 & .220 & -.908 & .437 \\
\hline $\begin{array}{l}\text { The university has only engaged qualified } \\
\text { professionals }\end{array}$ & 120 & -.393 & .221 & -.582 & .438 \\
\hline $\begin{array}{l}\text { The university has employees with the } \\
\text { desired levels of education }\end{array}$ & 122 & -.871 & .219 & .518 & .435 \\
\hline $\begin{array}{l}\text { The university has clear career development } \\
\text { plans }\end{array}$ & 121 & -.633 & .220 & -.481 & .437 \\
\hline
\end{tabular}

\section{Linearity Test for Human Capital Development}

The study conducted linearity test to determine whether the relationship between human capital development and organizational performance was linear or not. According to the results shown in Table 6, the significant deviation from linearity is 0.143 which is greater than 0.05 implying than there is a linear relationship between human capital development and organizational performance. 
Table 6 Linearity Test for Human Capital Development and Organizational Performance

\begin{tabular}{|c|c|c|c|c|c|c|c|}
\hline & & & $\begin{array}{l}\text { Sum of } \\
\text { Squares }\end{array}$ & $\mathrm{df}$ & $\begin{array}{l}\text { Mean } \\
\text { Square }\end{array}$ & $\mathrm{F}$ & Sig. \\
\hline \multirow{5}{*}{$\begin{array}{l}\text { Organizational } \\
\text { Performance * } \\
\text { Human Capital } \\
\text { Development }\end{array}$} & \multirow{3}{*}{$\begin{array}{l}\text { Between } \\
\text { Groups }\end{array}$} & (Combined) & 48.030 & 40 & 1.201 & 5.345 & .000 \\
\hline & & Linearity & 34.225 & 1 & 34.225 & 152.356 & .000 \\
\hline & & $\begin{array}{l}\text { Deviation } \\
\text { from Linearity }\end{array}$ & 13.805 & 39 & .354 & 1.576 & .143 \\
\hline & \multicolumn{2}{|c|}{ Within Groups } & 18.420 & 82 & .225 & & \\
\hline & \multicolumn{2}{|l|}{ Total } & 66.450 & 122 & & & \\
\hline
\end{tabular}

\section{Homoscedasticity Test for Human Capital Development}

The study findings had the homoscedasticity test evaluated for pairs of variables using the Levene statistic for the test of homogeneity of variances. The results are then given as shown in Table 7 . From the study findings of test for homogeneity, the probability associated with the Levene Statistic $(<0.099)$ is more than the level of significance (0.05) testing at 1-tail test 5\% significance level, the researcher concludes that the variance is homogeneous for human capital development.

Table 7 Homoscedasticity Test for Human Capital Development

\begin{tabular}{|l|l|l|l|}
\hline Levene Statistic & df1 & df2 & Sig. \\
\hline 2.342 & 22 & 82 & .099 \\
\hline
\end{tabular}

\section{Multicollinearity Test for Human Capital Development}

Multicollinearity is a state of very high intercorrelations or interassociations among the independent variables. Multicollinearity in the study was checked using the variance inflation factors (VIF). The VIF values of between 1 and 10 show that multicollinearity is not problematic in the study while VIF values of less than 1 and more than 10 indicate multicollinearity issues in the study. The findings obtained indicated that the VIF value for human capital development is 4.173 which is betweeen 1 and 10 and therefore multicollinearity was not problematic in the study. The findings are shown in Table 8.

Table 8 Multicollinearity Test for Human Capital Development

\begin{tabular}{|l|l|l|l|}
\hline \multirow{2}{*}{ Model } & \multicolumn{2}{|l|}{ Collinearity Statistics } \\
\cline { 3 - 4 } \multicolumn{1}{|l}{} & Tolerance & VIF \\
\hline \multirow{4}{*}{1} & Organization's Mission or Vision & .441 & 2.269 \\
\cline { 2 - 4 } & Human Capital Development & .240 & 4.173 \\
\cline { 2 - 4 } & Organizational Culture & .321 & 3.120 \\
\cline { 2 - 4 } & Ethical Values & .248 & 4.037 \\
\cline { 2 - 4 } & Strategic and Financial Controls & .257 & 3.898 \\
\hline
\end{tabular}

a. Dependent Variable: Organizational Performance 


\section{Hypothesis Testing for Human Capital Development}

Based on linear regression model, the study sought to establish the effect of human capital development on organizational performance. The following hypothesis was therefore tested:

Ho1: Human capital development does not affect the organizational performance in private universities in Kenya.

The study found that human capital development explained a significant proportion of variance in organizational performance, $\mathrm{R}^{2}=.515$. This implies that $51.5 \%$ of the proportion in organizational performance can be explained by human capital development in private universities in Kenya. Other factors not covered by this study therefore contribute to $49.5 \%$. Findings are as shown in Table 9.

Table 9 Model Summary for Human Capital Development

\begin{tabular}{|l|l|l|l|l|}
\hline Model & $\mathrm{R}$ & R Square & Adjusted R Square & $\begin{array}{l}\text { Std. Error of the } \\
\text { Estimate }\end{array}$ \\
\hline 1 & $.718^{\mathrm{a}}$ & .515 & .511 & .51607 \\
\hline
\end{tabular}

a. Predictors: (Constant), Human Capital Development

The findings indicated that the significance value in testing the reliability of the model for the relationship between human capital development and organizational performance was $F(1,122)=128.509, p=$ 0.00 . Therefore, the model is statistically significant in predicting the relationship between the study variables. Results are as presented in Table 10.

Table 10 ANOVA for Human Capital Development

\begin{tabular}{|l|l|l|l|l|l|l|}
\hline \multicolumn{2}{|l|}{ Model } & Sum of Squares & df & Mean Square & F & Sig. \\
\hline \multirow{4}{*}{1} & Regression & 34.225 & 1 & 34.225 & 128.509 & $.000^{\mathrm{b}}$ \\
\cline { 2 - 8 } & Residual & 32.225 & 121 & .266 & & \\
\cline { 2 - 8 } & Total & 66.450 & 122 & & & \\
\hline
\end{tabular}

a. Dependent Variable: Organizational Performance

b. Predictors: (Constant), Human Capital Development

The study found that human capital development significantly predicted organizational performance, $\beta=.718, t(122)=11.336, p=.000$. This finding implied rejection of the null hypothesis since the $\mathrm{p}$ value was less than $<.05$ set by the study. The study therefore concluded that human capital development significantly influences organizational performance in private universities in Kenya. The results are presented in Table 11.

Table 11 Regression Coefficients for Human Capital Development

\begin{tabular}{|c|c|c|c|c|c|c|}
\hline \multirow{2}{*}{\multicolumn{2}{|c|}{ Model }} & \multicolumn{2}{|c|}{$\begin{array}{l}\text { Unstandardized } \\
\text { Coefficients }\end{array}$} & \multirow{2}{*}{$\begin{array}{l}\text { Standardized } \\
\text { Coefficients } \\
\text { Beta } \\
\end{array}$} & \multirow[t]{2}{*}{$\mathrm{t}$} & \multirow[t]{2}{*}{ Sig. } \\
\hline & & B & Std. Error & & & \\
\hline \multirow[b]{2}{*}{1} & \begin{tabular}{|l} 
(Constant) \\
\end{tabular} & 1.124 & .244 & & 4.611 & .000 \\
\hline & $\begin{array}{ll}\begin{array}{l}\text { Human } \\
\text { Development }\end{array} & \text { Capital } \\
\end{array}$ & .755 & .067 & .718 & 11.336 & .000 \\
\hline
\end{tabular}

a. Dependent Variable: Organizational Performance 
The findings obtained in the study imply that for every one-unit change in human capital development, organizational performance increases by 0.755 hence implying a positive impact of human capital development on organizational performance.

\section{DISCUSSIONS AND CONCLUSION}

The study found that, human capital development explained a significant proportion of variance in organizational performance, $\mathrm{R}^{2}=.515$. This implies that $51.5 \%$ of the proportion in organizational performance can be explained by human capital development in private universities in Kenya. Human capital development significantly predicted organizational performance, $\beta=.718, t(122)=11.336, p=.000$. This finding implied rejection of the null hypothesis since the $\mathrm{p}$ value was less than $<.05$ set by the study.

\section{Conclusion}

The study concluded that human capital development explained a significant proportion of variance in organizational performance. In addition, the study concluded that human capital development significantly predicted organizational performance in private universities in Kenya. The study also concluded that for every one-unit change in human capital development, organizational performance increases by 0.755 hence implying a positive impact of human capital development on organizational performance.

\section{Recommendations}

The study found out that the universities did not have optimum number of employees, there were some instances where they engaged unqualified professionals, and employees did not fully participate in the formulation of human resource plans. The study therefore recommends that the universities need to involve all the employees in formulation of human resource plans to foster their performance, and also have optimum professional employees in realizing the universities' objectives

\section{References:}

1. Absar, M. N., Nimalathasan, B., \& Jilani, M. M. A. K. (2010). Impact of HR practices on organizational performance in Bangladesh. International Journal of Business Insights and Transformation, 3(2), 15-19.

2. Armstrong, M. (2017), Armstrong's Handbook of Performance Management: An Evidence-Based Guide to Delivering High Performance, 6th. Kogan PAGE: London. 
3. Beattie, V. \& Smith, S.J. (2010), "Human capital value creation and disclosure", Journal of Human Resource Costing \& Accounting, Vol. 14 No. 4, pp. 262-85.

4. Breakwell, G. M., \& Tytherleigh, M. Y. (2010). University Leaders and University Performance in the UK: is it „who "e leads or „where they lead that matters most? Higher Education Journal Vol 60 pp 491506

5. Boal, K. B. (2004). Strategic leadership. In: G. R. Goethals, G. J. Sorenson \& J. M. Burns (Eds), Encyclopedia of leadership (pp. 14971504). Thousand Oaks, CA: SAGE.

6. Choi, J.H., \& Lee, K.P. (2013). Effects of employees' perceptions on the relationship between HR practices and firm performance for Korean firms. Personnel Review, 42(5), 573-594.

7. Cooper, D. \& Schindlers, P. (2014). Business Research Methods 12th Ed. New York MCGRAW HILL Irwin

8. Creswell, J. W. (2014). Designing and Conducting Mixed Methods Research (4ndEd) Thousand Oaks, CA: SAGE.

9. Dimov, D. \& Shepherd, D. (2005), "Human capital theory and venture capital firms: exploring "home runs" and "strike outs", Journal of Business Venturing, Vol. 20, pp. 1-21.

10. Felício, J. A, Couto, E \& Caiado, J., (2014),"Human capital, social capital and organizational performance", Management Decision, Vol. 52 Iss 2 pp. $350-364$

11. Gurbuz, S. (2009). The effect of high performance HR practices on employees' job satisfaction. Journal of the School of Business Administration, 38(2), 110-123.

12. Gupta, V., \& Singh, S. (2010). Developing a set of high performance $H R M$ practices and exploring its relationship with $O C B$ and organizational justice. In SMA 2010 proceedings (pp. 464-469). Retrieved June 29, 2013, from http://mail.iiml.ac.in/ fpm9013/PaperID232.pdf

13. Hitt, M. A., Ireland, R. D. \& Hoskisson, R. E. (2015). Strategic Management: Competitiveness and Globalization (11th Edition), Cincinnati: Cengage Learning

14. Huselid, M.A., \& Becker, B.E. (2011). Bridging micro and macro domains: Workforce differentiation and strategic human resource management. Journal of Management, 37(2), 421-428.

15. Ireland, R. D., Hoskisson, R.E. \& Hitt, M. A. (2013), The Management of Strategy Concepts and Cases, $10^{\text {th }}$ ed. Mason, OH: South-Western CENGAGE Learning. 
16. Israel, G. D. (2009) Determining Sample Size. Program Evaluation and Organizational Development, Institute of Food and Agricultural Sciences (IFAS), University of Florida, Gainesville, USA

17. Kamukama, N., Ahiauzu, A., \& Ntayi, J. (2010), "Intellectual capital and performance: testing interaction effects", Journal of Intellectual Capital, Vol. 11 No. 4, pp. 554-574.

18. Khasawneh, S., \& Alzawahreh, A. (2012). High-performance work practices, innovation and perceived organizational performance: Evidence from the Jordanian service sector. African Journal of Business Management, 6(9), 3320-3326.

19. Lemaitre, M. (2009). Quality Assurance in a Changing World. INQAAHE Conference. Abu Dhabi, March.

20. Lim, L.L.K., Chan, C.C.A. \& Dallimore, P. (2009), "Perception of human capital measures: from corporate executives and investors", Journal of Business and Psychology, pp. 673-88.

21. Ministry of Education Science \& Technology, (2006) KESSP baseline; Process Monitoring System; and, Impact Evaluation Programme Report.

22. Morrill R. L. (2010) Strategic Leadership, Integrating Strategy and Leadership in Colleges and Universities, Rowman Littlefield Publishers INC, NY USA.

23. Muchiri, P., Pintelon, L, Gelders, \& Martin, H. (2010). Development of Maintenance Function Performance Measurement Framework Indicators. International Press.

24. Nel, C. \& Beudeker, N., (2009), Revolution: How to create a highperformance organization. Cape Town: The Village of Leaders Products.

25. Ployhart, R.E., Van Iddekinge, C.H. \& Mackenzie, W.I. (2011), "Acquiring and developing human capital in service contexts: the interconnectedness of human capital resources", The Academy of Management Journal, Vol. 54 No. 2, pp. 353-68.

26. Posthuma, R.A., Campion, M.C., Masimova, M., \& Campion, M.A. (2013). A high-performance work practices taxonomy: Integrating the literature and directing future research. Journal of Management, 20(10), 1-37.

27. Rao, J. N. (2015). Small-Area Estimation. John Wiley \& Sons, Ltd.

28. Sawyer, A. (2004), Challenges Facing African Universities: Selected Issues. African Studies Review, Vol.47, No.1, pp.1-59.

29. Standa, E (2007). Institutional Autonomy and Academic Freedom. The Uganda Higher Education Review. Journal of Higher Council for Education. Vol 4 No1 Pp.17-20. 
30. Tomal, D.R. \& Jones, K.J. (2015), “A comparison of core competencies of women and men leaders in the manufacturing industry", The Coastal Business Journal, 14 (1), 13-25.

31. Truss, C., Mankin, D. \& Kelliher, C. (2012). Strategic Human Resource Management. Oxford University Press, UK

32. UNESCO, (2014). Research and Experimental Development, Institute for Statistics

33. Varghese, N.V. (2006), Growth and expansion of private higher education in Africa. Paris: IIEP-UNESCO.

34. Varghese, N.V. (2004), UNESCO, Growth and Expansion of Higher Education, New Trends 